Genij Ortopedii. 2022. Vol. 28, no. 1. P. 91-96.

Original article

https://doi.org/10.18019/1028-4427-2022-28-1-91-96

\title{
Repair of open humerus fracture and extensive bone defect using bone grafting
} (case report)

\author{
Sharof M. Davirov ${ }^{\bowtie}$, Payzulla U. Urinboev
}

Samarkand branch of the Republican Specialized Scientific and Practical Medical Center for Traumatology and Orthopedics, Samarkand, Uzbekistan

\section{Corresponding author: Sharof M. Davirov, sharofd1976@mail.ru}

\section{Abstract}

Introduction Treatment of a patient with an open comminuted humerus fracture and an extensive bone defect is challenging and associated with high risk of a poor outcome, infection resulting from skin and soft tissue injury and considerable bone transport. The objective of the study is to demonstrate the experience with an open comminuted humerus fracture and an extensive bone defect treated with staged use of transosseous fixation with rod-and-wire device, autologous fibula graft and internal wiring. Material and methods We report a case of an open humerus fracture and an extensive bone defect treated with a bone replacement technique and followed up to 4 years. Results and discussion The limb was temporarily fixed with external fixation device extrafocally using wires and rods. A $24 \mathrm{~cm}$ autograft was harvested from the fibula. Osteosynthesis of the humerus and autografting were produced with the graft fixed using smooth wires and external fixation was provided using wires and rods. With consolidation of the humerus achieved, the external fixation device was dismantled and transosseous wires removed. Anatomical length of the segment was restored. Conclusion Combined techniques and technical means of external fixation, autologous graft, internal fixation with smooth wires facilitated complete restoration of the injured limb avoiding complications with a good clinical outcome.

Keywords: humerus, trauma, open fracture, bone defect, autobone, osteosynthesis, external fixation device, combined techniques

For citation: Davirov Sh.M., Urinboev P.U. Repair of open humerus fracture and extensive bone defect using bone grafting (case report). Genij Ortopedii, 2022, vol. 28, no 1, pp. 91-96. https://doi.org/10.18019/1028-4427-2022-28-1-91-96

\section{INTRODUCTION}

Treatment of patients with open comminuted fractures of the humerus with extensive bone defects poses a considerable risk of poor outcomes as there is a high possibility of developing infection complications due to damage of skin and soft tissues and presence of a significant bone defect. A large variety of treatment methods makes it difficult to choose the optimal approach in each particular case, which contributes to development of complications and poor outcomes. Cases reports provide assistance in choosing appropriate treatment methods and the successful experience can be shared.

At present the main method used for management of humeral fractures is internal fixation with various modifications of plates and nails [1]. Formation of defects in long bones can be caused by fractures, cystic formations, tumors, non-unions, infection and conditions associated with the need to perform bone resection [2]. In oncology, bone metastases are observed in breast (47-85\%), prostate (54-85\%), thyroid (38-60\%), and ovarian (up to $9 \%$ ) cancer [3]. An extensive bone defect can result from high-energy trauma, severe infection, malignancy, and is a major problem in limb salvage [4].

There is no single standard definition of a critical defect. Defects can be assessed both in relative and absolute terms, depending on the constitutional features of the patient. In general, a defect is considered to be of a "critical size" if that amount of bone loss does not close spontaneously despite surgical stabilization and requires further surgical intervention including various types of plasty [5].

The use of osteosynthesis with various external or internal fixators through an open surgical approach for such patients often ends in a poor outcome and does not providerestoration of the anatomical length of the segment. Open reduction, immediately after the injury, negatively affects the blood supply and leads to such complications as soft tissue necrosis, infection, wound suppuration. The need for additional immobilization in the postoperative period leads to contractures of adjacent joints of the upper limb and soft tissue atrophy. With extensive bone defects, internal fixation of the remaining fragments is impossible due to lack of the required amount of bone tissue, and an open reduction immediately after the open injury bears a danger of complications. A combination of different methods is an alternative that helps to reduce the possibility of a poor outcome of treatment.

There are data confirming the effectiveness of the technique of B.Sh.Minasov et al.; they report positive results in filling-in a large post-resection bone defect with a fragment of the fibula using microvascular anastomoses [6].

(c) Davirov Sh.M., Urinboev P.U., 2022 
A unique feature of distraction osteogenesis is the ability to completely induce new bone formation in the defect site. This procedure consists of three consecutive phases: a latent phase after the osteotomy and external fixation, a distraction phase, and a consolidation phase [7].

Modern trauma and orthopedics has a huge arsenal of methods for filling-in extensive post-traumatic defects of bone tissue of long bones. Currently, four directions can be distinguished: free bone grafting, filling-in bone defects with osteoreplacing and osteoinductive materials, bone transport according to G.A. Ilizarov and combined methods [8].

Management of bone defects according to Ilizarov and replantation into the defect site of a vascularized or free autograft [9], and also various kinds of free bone auto- and allografts [10] are considered relatively effective. Autografts performing the function of a bioprosthesis can be used as implants as well as artificial implants characterized by biocompatibility and sufficient level of strength. Autobone is an osteogenic, osteoconductive and osteoinductive plastic material [11], however harvesting autobone is associated with an additional sometimes significant injury and blood loss and is limited by the amount of available plastic material.
Management of bone defects according to Ilizarov is a perfect type of bone plasty when a well-vascularized bone graft is gradually formed in the affected area; the cover tissues and soft tissues are preserved. Theoretically it can create a tubular bone of any length and shape in the defect site [9].

Bone plasty using cancellous autobone is considered an effective means in achieving bone union in reoperations and is recommended by the majority of authors using internal fixation. However, consolidation is not always achieved [12-13].

Management of bone defects according to Ilizarov is considered the most biological method to fill-in bone defects. The disadvantages of this method are long period of treatment, bulky external device uncomfortable for the patient and the patient needs to be continuously followed by the doctor during distraction period lasting for up to 3-4 months.

Therefore it is preferable to combine different techniques, which provides high-quality treatment and takes less time.

The purpose of this work is to report our experience of treatment of an open comminuted fracture of the humerus with an extensive bone defect using different techniques in stages: transosseous osteosynthesis with a half-pin and wire external fixator, fibula bone graft, internal fixation.

\section{MATERIAL AND METHODS}

This article describes treatment in stages of an open humeral fracture with an extensive bone defect using an autograft, an external fixator and internal smooth wires, which allowed us to fill-in the defect preserving anatomical length of the limb and avoid complications.

Here's a clinical case with a 4-year follow-up: an open humeral fracture with an extensive bone-tissue defect was treated using bone transport.

Patient S.K., born in 1994, got injured in a road traffic accident on 29.09.2016. In a local hospital he was proposed amputation at the level of the humerus. He came to us on 10/10/2016.

The patient underwent clinical examination. $\mathrm{He}$ had a stitched wound of the posterior humerus with the signs of infection, limited function of the limb. Detailed questioning of the patient and revision showed that a large defect of the humerus was caused by loss of a significant bone fragment through the wound on the posterior surface of the elbow.

The patient underwent radiographic examination. He was diagnosed with an open double comminuted fracture of the left humerus with extensive defect of the meta-diaphysis and there was a fragment of the distal epiphysis and a defect of the articular surface of the elbow. There was an open fracture of the forearm; $22 \mathrm{~cm}$ defect of the humerus. II type according to GustilioAnderson classification of open fractures [14] (Fig. 1).

At the first stage of treatment on 12.10.2016 extrafocal osteosynthesis of the limb with the half-pin and wire external fixator was performed preserving the limb length without elimination of the defect (Fig. 2). Half-pin and wire fixator was used for minimally invasive closed reduction of the humerus; normal length of the segment was restored; longitudinal displacement of the segment was corrected.

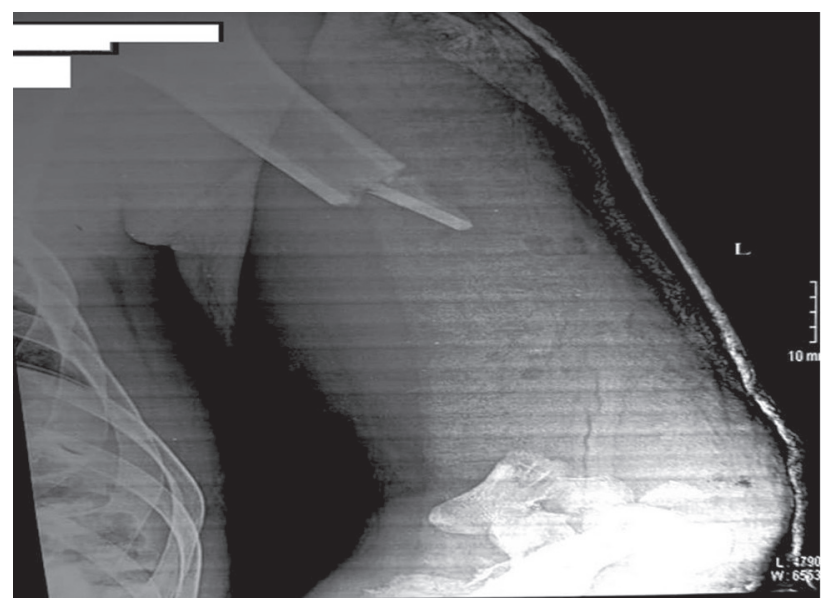

Fig. 1 X-ray of the left humerus of patient S.K., 1994 YOB, on admission on 10.10 .2016 


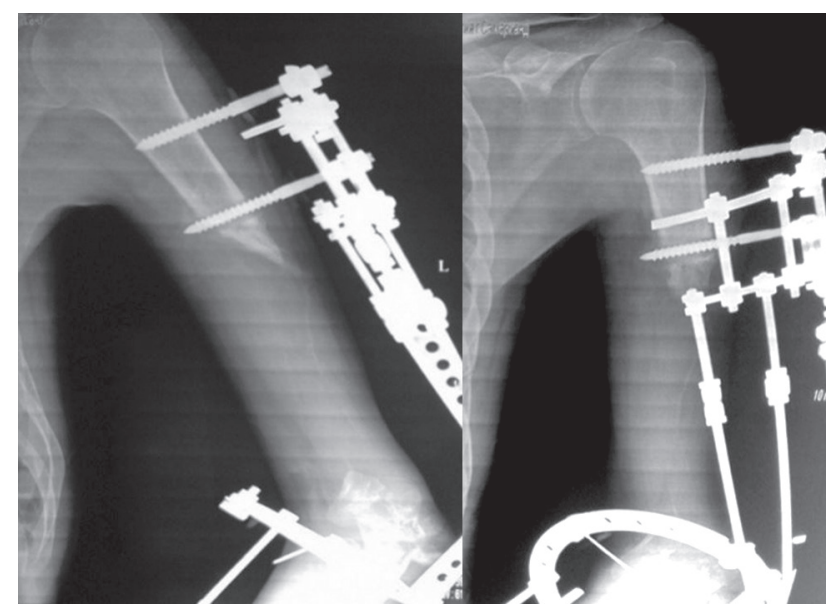

Fig. 2 X-rays of the left humerus of patient S.K., 1994 YOB, after application of the half-pin and wire external fixator 12.10.2016

When infection in the wound manifested bacteriological laboratory studies were performed and antibiotic therapy commenced; infection was arrested. Analysis of the microbial landscape of the wound showed presence of Staphylococcus aureus. Antibiotic therapy, semisynthetic penicillins (mainly oxacillin), systemic medication were prescribed and daily surgical treatment of the soft tissue wound was done. The patient became active after the first stage of the surgery and remained under observation.

After the soft tissue wound healed the second stage of surgical treatment was performed on 14.12.2016. The half-pin and wire external fixator was temporarily removed and the bone defect of the humerus was filledin with a 24-cm fibula autograft (Fig. 3).

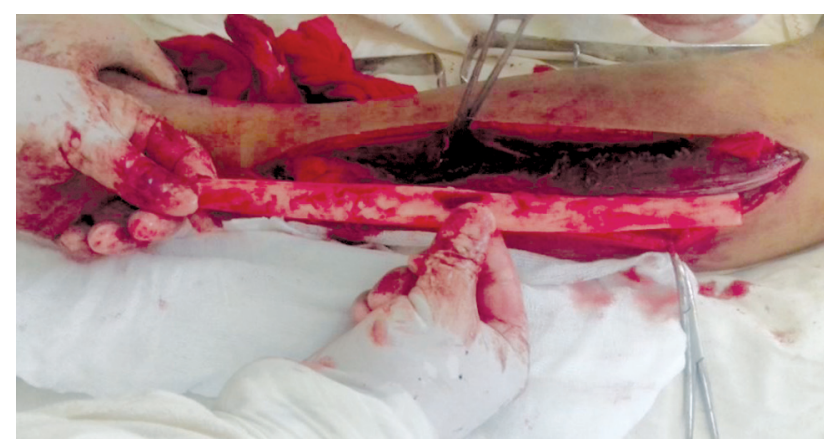

Fig. 3 Harvesting the 24-cm fibula autograft

The autograft was placed in the site of the humeral defect through the two mini-incisions. The autograft was put through the first mini-incision from the side of the distal humeral fragment; it was pushed up to the proximal fragment. Then the autograft was inserted into the medullary canal of the proximal fragment by $2 \mathrm{~cm}$. For the purpose of the insertion and fixation of the graft to the proximal fragment the second miniincision was made; the proximal end of the fragment was exposed.
After insertion of the graft into the medullary canal of the proximal fragment of the humerus the autograft was fixed with three smooth wires. For fixation of the distal end of the graft to the distal humerus the first miniincision was used; the ends of the graft and the distal fragment were put in contact and fixed with five smooth wires, which were inserted also through the fragment of the epiphysis into the articular surface as there was a defect of the articular surface of the distal humerus.

The half-pin and wire Ilizarov external fixator was assembled to provide immobilization (Fig. 4, 5).

After the autograft and humeral fragments united on 04.04.2017 the external fixator was removed; the wires placed through the contact sites of the graft and the humeral fragments were removed through the miniincisions (Fig. 5).
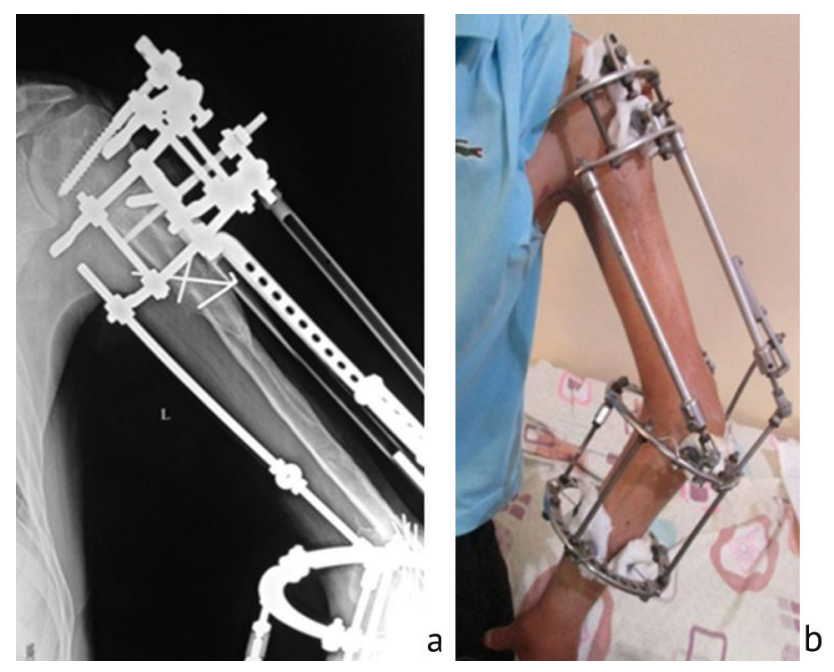

Fig. 4: a - X-ray of the humerus after putting in the graft and application of the external fixator; $b$ - photo of the patient's limb after the second stage of the surgery
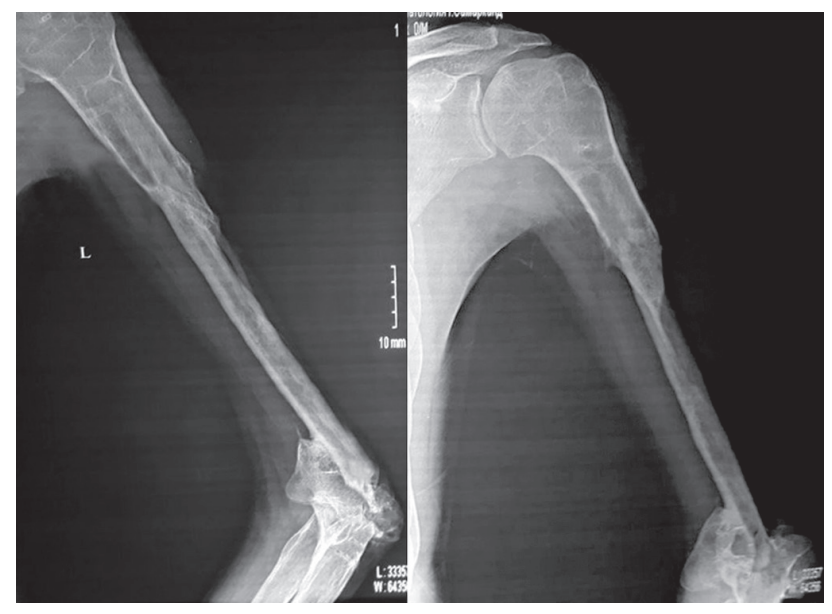

Fig. 5 X-rays of the left humerus of the patient after removal of the external fixator and the wires

At the first stage, in the acute period of trauma, the temporary transosseous extrafocal fixation of the limb was done with a half-pin and wire external fixator. At the second stage the 24-cm fibula graft was harvested. 
Osteosynthesis of the humerus and graft with the smooth wires and filling-in of the bone defect were performed. The half-pin and wire external fixator was assembled again. The external fixator is effective for immobilization of the limb; unlike plaster cast is makes it possible to treat the soft tissues and monitor the wound healing [15]. After the bone union was achieved the external fixator and the internal wires were removed.

\section{RESULTS}

Full recovery of the integrity of the segment was achieved after treatment of the patient with the humeral fracture in stages. The limb contains natural biological tissue without any foreign bodies (Fig. 5). An integrated bone frame was formed; the clinical examination proved it to be capable of taking longitudinal, rotational, twisting stress. The treatment result was evaluated according to the scale "Elbow surgery evaluation", which after 24 months corresponded to a satisfactory result (50-69 points) [16]. There was full function in the elbow joint.

At 4 years follow-up (Fig. 6) on 10.01.2020 the patient had fibrous ankylosis of the elbow joint in functional position. At the initial stage of treatment in a local hospital the patient had been proposed removal of a part of the limb; the treatment we conducted allowed us to preserve the limb, the fibrous ankylosis of the elbow developed because the articular surface of the humerus had been damaged during trauma and it had caused its defect. The patient has all functions in the left arm and works as a motor driver; he is pleased with the result of treatment despite the ankylosis.

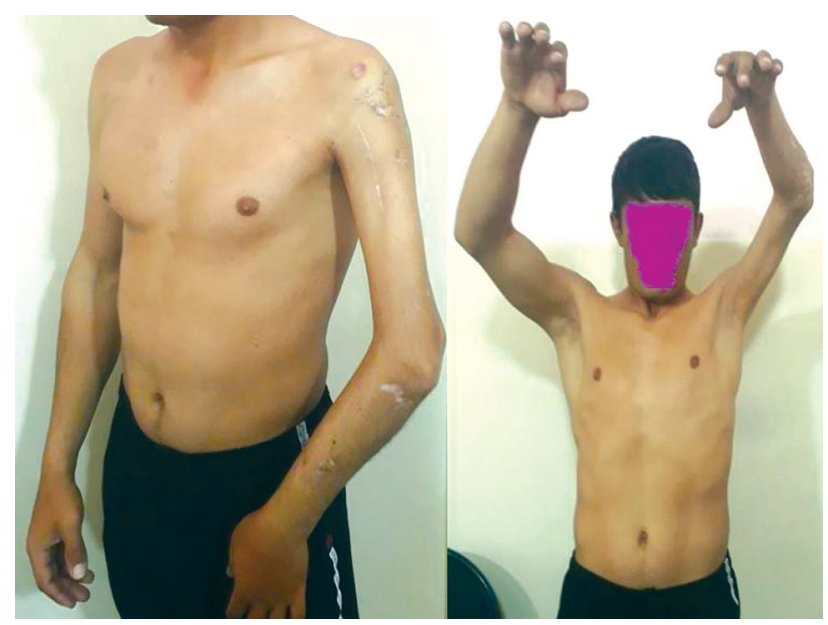

Fig. 6 Photo of the patient in 4 years after completion of treatment

\section{DISCUSSION}

The method of choice for management of open fractures of the humerus is extrafocal osteosynthesis or open osteosynthesis depending on the character of injury. Using open osteosynthesis in the early posttraumatic period in presence of extensive soft tissue wounds with primary biological contamination, multi-fragmental fractures is associated with infection complications.

According to the available literature data at the current level of technological development open fractures result in osteomyelitis in 5.3-75.4\% of cases, gun-shot fractures result in osteomyelitis in 34.2-82.3\% of cases and planned orthopaedic and trauma surgeries in $1.5-33.2 \%$ of cases [17].

A. Bagherifard, H. Ghandhari et al. report that application of massive avascular grafts is associated with a risk of secondary infection, long remodeling and osteolysis [18]. Unlike the literature data, our patient did not have infection complications and osteolysis.

Long treatment, need for a few stages and subjective discomfort are significant drawbacks in the management of bone defects according to Ilizarov [19]. However, in case of our patient at the initial stage of treatment the patient had been proposed an amputation; despite long treatment in stages we succeeded in limb salvage and avoided amputation.
Autograft is an osteogenic, osteoconductive and osteoinductive plastic material [11], however harvesting the autograft is associated with additional, sometimes significant trauma and blood loss and limited amount of plastic material available for harvesting. Mattar J.Jr., Azze R.J. et al. report that vascularized bone plasty provides higher biomechanical strength than non-vascularized [20]. In our case we used $24 \mathrm{~cm}$ autograft, which is considered a massive graft; we observed neither complications in the bed of the graft nor complications associated with the graft acceptance.

Such traumas set a task before the doctor to using various kinds of treatment and their combinations in order to achieve a successful result. An external fixator is effective for immobilization of the limb; unlike plaster cast is makes it possible to treat the soft tissue wound and monitor the wound healing. Based on studying the long-term anatomic and functional result we can conclude that using fibula for the purpose of filling-in posttraumatic diaphyseal-metaphyseal defect of the humerus is beneficial and effective. However, our report is based on the treatment result of one patient and we do not find it appropriate to make general conclusion. 


\section{CONCLUSION}

Combination of different techniques and technical devices of external and internal fixation allowed us to completely restore the injured limb, avoid complications and achieve satisfactory clinical result in this patient. The described technique for filling-in bone defect is widely used in Russian and international medical institutions.

A wide variety of treatment methods makes it difficult to choose the optimal ones and avoid complications and poor outcomes. Presence of conclusive cases reports helps to make a well-founded choice of the method and share the successful experience.

The outcome of filling-in the large defect of the humerus by performing treatment in stages and using the bone grafting and external fixation proves that in this situation there is a beneficial alternative to limb amputation for extensive defects of the humerus.

\section{REFERENCES}

1. Belenkii I.G., Maiorov B.A., Li S.Kh. Operativnoe lechenie perelomov diafiza plechevoi kosti. Sovremennyi vzgliad na problemy i puti ikh resheniia [Surgical treatment of humeral shaft fractures. Modern view of problems and ways to solve them]. Fundamentalnye Issledovaniia, 2014, no. 10-9, pp. 1849-1857. (in Russian)

2. Netyl'ko G.I., Rumakin V.P., Konev V.A. Eksperimentalnoe modelirovanie kostnogo defekta so sklerozirovannoi stenkoi [Experimental modeling of bone defect with a sclerosal wall]. Genij Ortopedii, 2014, no. 3, pp. 72-76. (in Russian)

3. Saidkulov B., Abduraxmonov J., Rahimov M.N., Raufov F. Recurrent ovarian cancer: mechanisms of development of peritoneal malignant ascities. Eurepean Journal of Molecular \& Clinical Medicine, 2020, vol. 7, no. 2, pp. 2423-2428.

4. Mauffrey C., Barlow B.T., Smith W. Management of segmental bone defects. J. Am. Acad. Orthop. Surg., 2015, vol. 23, no. 3, pp. 143-153. DOI: 10.5435/JAAOS-D-14-00018.

5. Keating J.F., Simpson A.H., Robinson C.M. The management of fractures with bone loss. J. Bone Joint Surg. Br., 2005, vol. 87, no. 2, pp. 142-150. DOI: 10.1302/0301-620x.87b2.15874.

6. Minasov B.Sh., Biktasheva E.M., Valeev M.M., Yakupov R.R., Minasov T.B., Mavlyutov T.R. Tsirkuliarnaia rezektsiia loktevoi kosti pri gigantokletochnoi opukholi s odnomomentnoi plastikoi vaskuliarizovannym fragmentom malobertsovoi kosti [Circular resection for giant cell tumor of the ulna combined with vascularized fibular fragment autoplasty]. Genij Ortropedii, 2019, vol. 2, no. 3, pp. 388-392.

7. Li W., Zhu S., Hu J. Bone regeneration is promoted by orally administered bovine lactoferrin in a rabbit tibial distraction osteogenesis model. Clin. Orthop. Relat. Res., 2015, vol. 473, no. 7, pp. 2383-2393. DOI: 10.1007/s11999-015-4270-5.

8. Shastov A.L., Kononovich N.A., Gorbach E.N. Problema zameshcheniia posttravmaticheskikh defektov dlinnykh kostei v otechestvennoi travmatologo-ortopedicheskoi praktike [Management of posttraumatic long bone defects in the national orthopedic practice (literature review)]. Genij Ortopedii, 2018, vol. 24, no. 2, pp. 252-257.

9. Shevtsov V.I., Borzunov D.Iu. Reabilitatsiia patsientov s defektami i lozhnymi sustavami dlinnykh kostei, sovremennoe sostoianie problemy [Rehabilitation of patients with long bone defects and pseudoarthroses, current state of the problem]. Genij Ortopedii, 2008, no. 4, pp. 48-54. (in Russian)

10.Nikolenko V.K., Babich M.I., Gritsiuk A.A., Brizhan L.K., Lukomskii M.I. Lechenie ognestrelnykh defektov dlinnykh kostei nizhnikh konechnostei [Treatment of gunshot defects of the lower limb long bones]. Vestnik Travmatologii $i$ Ortopedii im. N.N. Priorova, 2007, no. 2, pp. 64-70. (in Russian)

11.Finkemeier C.G. Bone-grafting and bone-graft substitues. J. Bone Joint Surg. Am., 2002, vol. 84, no. 3, pp. $454-464$. DOI: 10.2106/00004623-200203000-00020.

12.Koutalos A., Varitimidis S., Dailiana Z., Bargiotas K., Koutsogiannis A., Malizos K.N. Operative management of humeral nonunions. Factors that influence the outcome. Acta. Orthop. Belg., 2015, vol. 81, no. 3, pp. 501-510.

13.Jones D.B. Jr., Rhee P.C., Bishop A.T., Shin A.Y. Free vascularized medial femoral condyle autograft for challenging upper extremity nonunions. Hand. Clin., 2012, vol. 28, no. 4, pp. 493-501. DOI: 10.1016/j.hcl.2012.08.005.

14.Kim P.H., Leopold S.S. In brief: Gustilo-Anderson Classification. Clin. Orthop. Relat. Res., 2019, vol. 477, no. 10, pp. 2388. DOI: 10.1097/CORR.0000000000000950.

15.Davirov Sh.M., Urinboev P.U. Lechenie patsienta s otkrytym perelomom kostei predplechia i obshirnym defektom kostnoi tkani (sluchai iz praktiki) [Repair of an open forearm fracture and extensive bony loss (case report)]. Genij Ortopedii, 2021, vol. 27, no. 1, pp. 87-91.

16.Merkulov V.N., Dergachev D.A., Dorokhin A.I. Artroplastika pri lechenii posttravmaticheskikh kontraktur i ankilozov loktevogo sustava u detei [Arthroplasty in treatment of posttraumatic contractures and ankyloses of the elbow in children]. Detskaia Khirurgiia, 2014, vol. 18, no. 4, pp. 34-38. (in Russian)

17.Kliushin N.M. Metod Ilizarova v gnoinoi osteologii [Ilizarov method in purulent osteology]. Kurgan, Printexpress], 2019. s. 7-9. (in Russian)

18.Bagherifard A., Ghandhari H., Jabalameli M., Rahbar M., Hadi H., Moayedfar M., Sajadi M.M., Karimpour A. Autograft versus allograft reconstruction of acute tibial plateau fractures: a comparative study of complications and outcome. Eur. J. Orthop. Surg. Traumatol., 2017, vol. 27, no. 5, pp. 665-671. DOI:10.1007./s00590-016-1863-y. 
19.Gaillard J., Bourcheix L.M., Masquelet A.C. Perforators of the fibular artery and suprafascial network. Surg. Radiol. Anat., 2018, vol. 40, no. 8, pp. 927-933. DOI: 10.1007/s00276-017-1927-7.

20.Mattar J. Jr., Azze R.J., Ferreira M.C., Starck R., Canedo A.C. Vascularized fibular graft for management of severe osteomyelitis of the upper extremity. Microsurgery, 1994, vol. 15, no. 1, pp. 22-27. DOI: 10.1002/micr.1920150108.

The article was submitted 16.03.2021; approved after reviewing 14.09.2021; accepted for publication 23.12.2021.

\section{Information about the authors:}

1. Sharof M. Davirov - M.D., sharofd1976@mail.ru

2. Payzulla U. Urinboev - Doctor of Medical Sciences, Professor. 